Article

\title{
New Antifungal Pyranoisoflavone from Ficus tikoua Bur.
}

\section{Shaopeng Wei, Wenjun Wu and Zhiqin Ji *}

College of Plant Protection and Institute of Pesticide Science, Northwest A \& F University, Yangling, Shaanxi 712100, China; E-Mails: weishaopeng8888@163.com (S.W.); wuwenjun@nwsuaf.edu.cn (W.W.)

* Author to whom correspondence should be addressed; E-Mail: jizhiqin@nwsuaf.edu.cn; Tel.: +86-29-87092191; Fax: +86-29-87093987.

Received: 4 May 2012; in revised form: 5 June 2012 / Accepted: 7 June 2012 /

Published: 14 June 2012

\begin{abstract}
Considering the undesirable attributes of synthetic fungicides and the availability of Ficus species in China, the stem of Ficus tikoua Bur. was investigated. One new antifungal pyranoisoflavone, 5,3',4'-trihydroxy-2",2"-dimethylpyrano (5",6":7,8) isoflavone (1), together with two known isoflavones, wighteone (2) and lupiwighteone (3) (with previously reported antifungal activities), were isolated from ethyl acetate extract by bioassay-guided fractionation. Their structures were determined by spectroscopic analysis, such as NMR $\left({ }^{1} \mathrm{H}-{ }^{1} \mathrm{H}\right.$ COSY, HMQC, HMBC and NOESY), IR, UV and HRMS, as well as ESI-MS $^{\mathrm{n}}$ analyses. The antifungal activities of 1-3 against Phytophthora infestans were evaluated by direct spore germination assay, and the $\mathrm{IC}_{50}$ values were $262.442,198.153$ and $90.365 \mu \mathrm{g} \cdot \mathrm{mL}^{-1}$, respectively.
\end{abstract}

Keywords: Ficus tikoua Bur.; pyranoisoflavone; antifungal activity

\section{Introduction}

The plants of the Ficus genus have attracted considerable attention from pharmacologists due to a wide range of biological properties. Ficus tikoua Bur., a wood plant of the Ficus genus, is widely distributed in southern China, India, Vietnam and Laos. It has long been used in traditional folk medicine to treat diseases, such as chronic bronchitis, diarrhea, dysentery, rheumatism, edema, impetigo, and so on [1-3]. Previous studies show that the extracts of the plant exhibit excellent antifungal activity against many species of pathogens, such as Pseudoperonospora cubensis, Phytophthora infestans and 
Plasmopara viticola [4]. The plant can be considered as a potential botanical pesticide. However, to our best knowledge, no references about its antifungal constituents have been published.

Considering the undesirable attributes of synthetic fungicides, there is an urgent need to develop alternative treatments that are less hazardous to humans and animals, and that impact less on the environment. Herein, we report the isolation, structural elucidation and antifungal activities of a new pyranoisoflavone, named 5,3',4'-trihydroxy-2",2"-dimethylpyrano (5",6":7,8) isoflavone (1), along with other two known isoflavones, wighteone (2) and lupiwighteone (3), whose antifungal activities were reported previously [5] (Figure 1).

Figure 1. Structures of compounds 1-3.
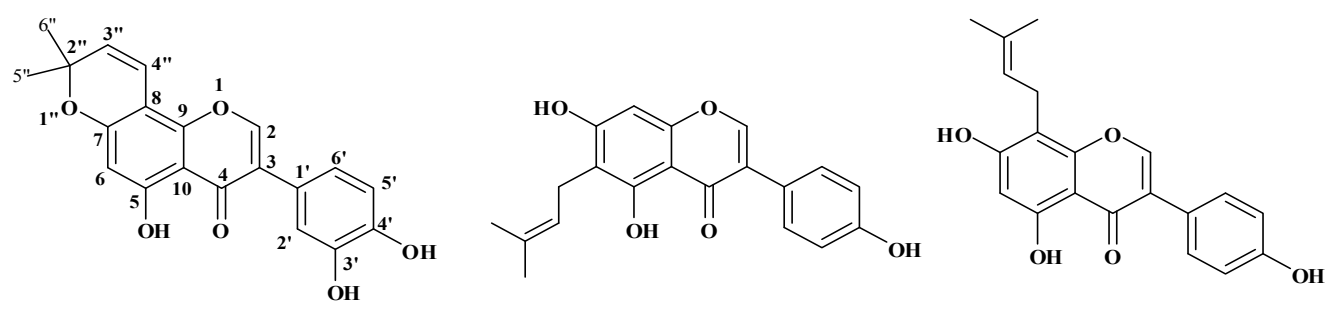

\section{Results and Discussion}

\subsection{Isolation and Structural Elucidation}

The ethyl acetate-soluble fraction of the crude extract acquired for this study was successively subjected to column chromatography to yield compounds $\mathbf{1}-\mathbf{3}$. Their structures were elucidated by the methods of UV, IR, HR-ESI/MS, ESI-MS/MS and NMR.

Compound 1 was obtained as a pale yellow amorphous powder. The molecular formula $\mathrm{C}_{20} \mathrm{H}_{16} \mathrm{O}_{6}$ was deduced from its HR-ESI-MS (observed $m / z 353.1010[\mathrm{M}+\mathrm{H}]^{+}$, calcd. for $\mathrm{C}_{20} \mathrm{H}_{17} \mathrm{O}_{6} 353.1020$ ) and NMR data. IR absorption at 3410, 1686 and $1580 \mathrm{~cm}^{-1}$ indicated the presence of hydroxyl function, carbonyl and aromatic ring. Analysis of its NMR (Table 1) spectral data suggested the presence of the skeleton of isoflavone due to a singlet resonance at $\delta_{\mathrm{H}} 8.01$ and corresponding olefinic oxymethine signal at $\delta_{\mathrm{C}} 156.85$ are characteristic of $\mathrm{H}-2$ and C-2, respectively [6-8]. The NMR spectral also revealed the presence of phenol and ketone moieties. ${ }^{13} \mathrm{C}-\mathrm{NMR}$ (DEPT) spectrum of 1 displayed 20 signals, which were assigned to two methyls, seven methines and eleven quaternary carbons (including one keto carbonyl at $\delta_{\mathrm{c}}$ 182.8) in agreement with the molecular formula. ${ }^{1} \mathrm{H}-\mathrm{NMR}$ spectrum showed a six-proton singlet at $\delta_{\mathrm{H}} 1.45$ assignable to a gem-dimethyl group and two doublets $(J=10.1 \mathrm{~Hz})$ at 6.68 and 5.71, integrating for one proton each, corresponding to vinylic protons (H-4" and H-3", respectively) suggesting the presence of a 2,2-dimethylchromen residue in compound 1 [9]. The signals observed at $\delta 6.39(\mathrm{~d}, J=2.4,1 \mathrm{H}), \delta 7.03(\mathrm{~d}, J=8.3,1 \mathrm{H})$ and $\delta 6.37(\mathrm{dd}, J=2.4,8.3,1 \mathrm{H})$ in the ${ }^{1} \mathrm{H}$-NMR of 1 were attributed to the 2', 5', 6'-protons, respectively. That the 2,2-dimethylchromen residue is at the 7,8-position in $\mathbf{1}$ was established based on the analysis of heteronuclear multiple-bond correlation (HMBC) spectrum and by comparing the spectral data of its monomethyl ether with that reported in literature [10,11]. The ${ }^{1} \mathrm{H}-{ }^{1} \mathrm{H}$ correlation spectroscopy (COSY) NMR spectral revealed it was possible to establish the proton sequences by the following cross-peaks: $\mathrm{H}\left(5^{\prime}\right) / \mathrm{H}\left(6^{\prime}\right)$ and $\mathrm{H}$ 
$\left(3^{\prime \prime}\right) / \mathrm{H}\left(4^{\prime \prime}\right)$. Its HMBC spectrum showed many informative correlations, such as $\mathrm{H}(2) / \mathrm{C}(3), \mathrm{C}(4), \mathrm{C}(9)$ and $\mathrm{C}\left(1^{\prime}\right) ; \mathrm{H}(6) / \mathrm{C}(5), \mathrm{C}(7), \mathrm{C}(8)$ and $\mathrm{C}(10) ; \mathrm{H}\left(2^{\prime}\right) / \mathrm{C}(3), \mathrm{C}\left(3^{\prime}\right)$ and $\mathrm{C}\left(4^{\prime}\right) ; \mathrm{H}\left(5^{\prime}\right) / \mathrm{C}\left(1^{\prime}\right), \mathrm{C}\left(4^{\prime}\right)$ and $\mathrm{C}\left(6^{\prime}\right)$; $\mathrm{H}\left(6^{\prime}\right) / \mathrm{C}\left(1^{\prime}\right), \mathrm{C}\left(4^{\prime}\right)$ and $\mathrm{C}\left(5^{\prime}\right) ; \mathrm{H}\left(3^{\prime \prime}\right) / \mathrm{C}(8)$ and $\mathrm{C}\left(2^{\prime \prime}\right) ; \mathrm{H}\left(4^{\prime \prime}\right) / \mathrm{C}(7)$ and $\mathrm{C}\left(2^{\prime \prime}\right)$ (Figure 2).

Table 1. The ${ }^{1} \mathrm{H}$ and ${ }^{13} \mathrm{C}-\mathrm{NMR}$ chemical shifts of compound $\mathbf{1}$ in $\mathrm{CD}_{3} \mathrm{OD}$.

\begin{tabular}{cccc}
\hline Positions & $\boldsymbol{\delta}_{\mathbf{H}}(\mathbf{p p m})$ & $\boldsymbol{\delta}_{\mathbf{C}}(\mathbf{p p m})$ & HMBC \\
\hline 2 & $8.01(\mathrm{~s}, 1 \mathrm{H})$ & $156.85(\mathrm{CH})$ & $\mathrm{C}-3, \mathrm{C}-4, \mathrm{C}-9, \mathrm{C}-1^{\prime}$ \\
3 & $/$ & $122.66(\mathrm{C})$ & \\
4 & $/$ & $182.84(\mathrm{CO})$ & \\
5 & $/$ & $157.58(\mathrm{C})$ & \\
6 & $6.36(\mathrm{~s}, 1 \mathrm{H})$ & $95.86(\mathrm{CH})$ & $\mathrm{C}-5, \mathrm{C}-7, \mathrm{C}-8, \mathrm{C}-10$ \\
7 & $/$ & $160.90(\mathrm{C})$ & \\
8 & $/$ & $106.56(\mathrm{C})$ & \\
9 & $/$ & $158.87(\mathrm{C})$ & \\
10 & $/$ & $106.93(\mathrm{C})$ & \\
$1^{\prime}$ & $/$ & $110.63(\mathrm{C})$ & \\
$2^{\prime}$ & $/$ & $133.23(\mathrm{CH})$ & $\mathrm{C}-3, \mathrm{C}-3^{\prime}, \mathrm{C}-4^{\prime}$ \\
$3^{\prime}$ & $/$ & $160.25(\mathrm{C})$ & \\
$4^{\prime}$ & $6.39(\mathrm{~d}, J=2.4,1 \mathrm{H})$ & $157.78(\mathrm{C})$ & \\
$5^{\prime}$ & $7.03(\mathrm{~d}, J=8.3,1 \mathrm{H})$ & $104.23(\mathrm{CH})$ & $\mathrm{C}-1^{\prime}, \mathrm{C}-4^{\prime}, \mathrm{C}-6^{\prime}$ \\
$6^{\prime}$ & $6.37(\mathrm{dd}, J=2.4,8.3,1 \mathrm{H})$ & $108.13(\mathrm{CH})$ & $\mathrm{C}-1^{\prime}, \mathrm{C}-4^{\prime}, \mathrm{C}-5^{\prime}$ \\
$2^{\prime \prime}$ & $/$ & $79.25(\mathrm{C})$ & \\
$3^{\prime \prime}$ & $5.71(\mathrm{~d}, J=10.1,1 \mathrm{H})$ & $129.67(\mathrm{CH})$ & $\mathrm{C}-8, \mathrm{C}-2^{\prime \prime}$ \\
$4^{\prime \prime}$ & $6.68(\mathrm{~d}, J=10.1,1 \mathrm{H})$ & $116.09(\mathrm{CH})$ & $\mathrm{C}-7, \mathrm{C}-2^{\prime \prime}$ \\
$5^{\prime \prime}$ & $1.45(\mathrm{~s}, 3 \mathrm{H})$ & $28.55(\mathrm{CH})$ & \\
$6^{\prime \prime}$ & $1.45(\mathrm{~s}, 3 \mathrm{H})$ & $28.55(\mathrm{CH})$ & \\
\hline
\end{tabular}

$\delta_{\mathrm{C}}(\mathrm{ppm}) 125 \mathrm{MHz} ; \delta_{\mathrm{H}}(\mathrm{ppm}) 500 \mathrm{MHz}$; multiplicities; $J$ values $(\mathrm{Hz})$ in parentheses. Assignments are based on DEPT and ${ }^{1} \mathrm{H}^{-13} \mathrm{C}$ (HSQC and HMBC) experiments.

Figure 2. Partial structure of 1 solved by heteronuclear multiple-bond correlation (HMBC) and ${ }^{1} \mathrm{H}-{ }^{1} \mathrm{H}$ COSY spectra.

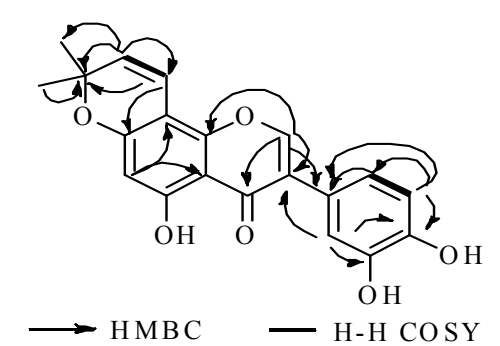

In order to validate the structure described above, the cleavage of compound $\mathbf{1}$ was studied by ESI-MS $^{\mathrm{n}}$ ether in negative mode. The major product ions of $\mathbf{1}$ observed in the tandem mass spectrometric experiments can be ascribed to five fragmentation processes according to the published literature and the five fragmentation processes, I-V, are shown in Scheme 1 [12-14]. The product ion mass spectrum of $[\mathrm{M}-\mathrm{H}]^{-}$shows two major product ions at $\mathrm{m} / \mathrm{z} 307$ and $\mathrm{m} / \mathrm{z} 217$, respectively. Fragment observed at $\mathrm{m} / \mathrm{z} 307$ might be originated from the neutral loss of $\mathrm{CO}_{2}$, and the $\mathrm{m} / \mathrm{z} 217$ ion 
has been formed in a retro-Diels Alder (RDA) reaction, that is, by fragmentation process V. Further, the product ions at $\mathrm{m} / \mathrm{z} 173, \mathrm{~m} / \mathrm{z} 201, \mathrm{~m} / \mathrm{z} 189$ and $\mathrm{m} / \mathrm{z} 149$ are the product of fragmentation processes I, II, III, IV, respectively. Finally, compound 1 was identified as 5,3',4'-trihydroxy-2",2"-dimethylpyrano $(5 ", 6 ": 7,8)$ isoflavone.

Compounds $\mathbf{2}$ and $\mathbf{3}$ were two known isoflavones, wighteone (2) and lupiwighteone (3), based on UV, IR, ESI-MS, ${ }^{1} \mathrm{H}$ - and ${ }^{13} \mathrm{C}-\mathrm{NMR}$ spectroscopic data [15-17].

\subsection{Antifungal Activities}

Antifungal activities of compounds 1-3 against $P$. infestans were investigated by spore germination assay, and the $\mathrm{IC}_{50}$ values of $\mathbf{1 - 3}$ were $262.442,198.153$ and $90.365 \mu \mathrm{g} \cdot \mathrm{mL}^{-1}$, respectively.

As showed in Table 2, antifungal potency of compounds $\mathbf{2}$ and $\mathbf{3}$ was greater than that of compound 1. Considering the fact that natural compounds can have synergistic antifungal activities [18], the interactions between compounds 1-3 need to be investigated, and we will report on this progress in the future.

Table 2. Antifungal activities of compounds 1-3 against $P$. infestans.

\begin{tabular}{ccc}
\hline Compounds & $\mathbf{I C}_{\mathbf{5 0}}\left(\boldsymbol{\mu g} \cdot \mathbf{m L}^{-\mathbf{1}}\right)$ & SD \\
\hline 1 & 262.442 & 0.16 \\
2 & 198.153 & 0.67 \\
3 & 90.365 & 0.45 \\
Pyrimethanil & 210.050 & 0.77 \\
\hline
\end{tabular}

\section{Experimental Section}

\subsection{General Experimental Procedures}

Melting points were measured on a WPR apparatus and are uncorrected (Shanghai Jingke Co.). IR spectra were recorded on a Nicolet FT-IR 750 spectrometer. UV spectra were obtained using a Shimadzu UV-2401A spectrometer. Optical rotations were measured with a Horiba SEPA300 polarimeter. ESI-MS/MS and HR-ESI-MS spectra were obtained on a Finnigan LCQ Advantage ion-trap mass spectrometer (Thermo Fisher Co.) and an APEX II FT-ICR mass spectrometer (Bruker Daltonics Inc.). ${ }^{1} \mathrm{H},{ }^{13} \mathrm{C}$ NMR, DEPT, HSQC, HMBC and NOESY spectra were obtained on Bruker Avance III-500 NMR spectrometer (Bruker Daltonics Inc.), and TMS as internal standard $\left({ }^{1} \mathrm{H}\right.$ at $500 \mathrm{MHz},{ }^{13} \mathrm{C}$ at $125 \mathrm{MHz}$, respectively).

\subsection{Plant Material}

The stem of F. tikoua Bur. was collected in Hongya County, Sichuan Province, P.R. China, in September 2009, and identified at the College of Life Sciences, Northwest Agricultural \& Forestry University. The voucher specimens (samples No. NWAU2009-FT15) were deposited with the College of Life Sciences, Northwest Agricultural \& Forestry University. 
Scheme 1. CID spectrum (A) and the proposed fragmentation pathways (B) of compound $\mathbf{1}$ in negative mode.

Negative ESI-MS² ( [M-H]- ,351)

DG07-\#140-146 RT: 2.29-2.43 AV: 7 NL: 6.63E5

T: - c ESI Full ms2 351.00@40.00 [ 95.00-800.00]

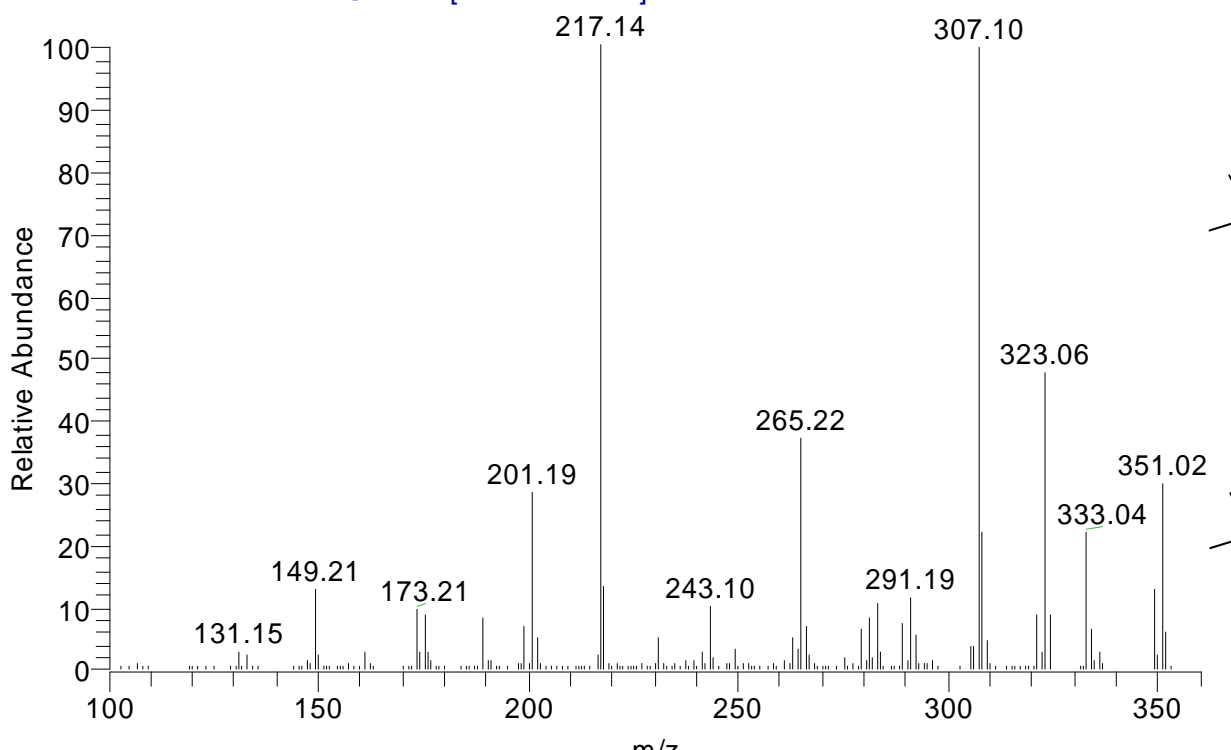

A

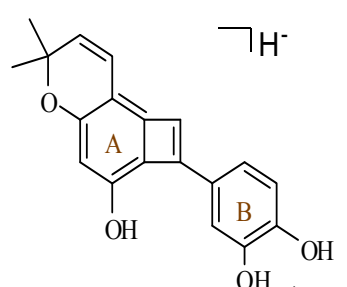

$\mathbf{m} / \mathbf{z} 307$<smiles>CC1(C)C=Cc2c#cccc2O1</smiles>

$\mathrm{OH}$

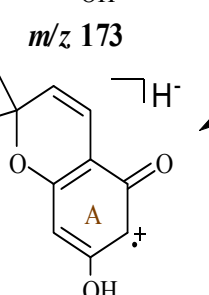

$m / z 189$

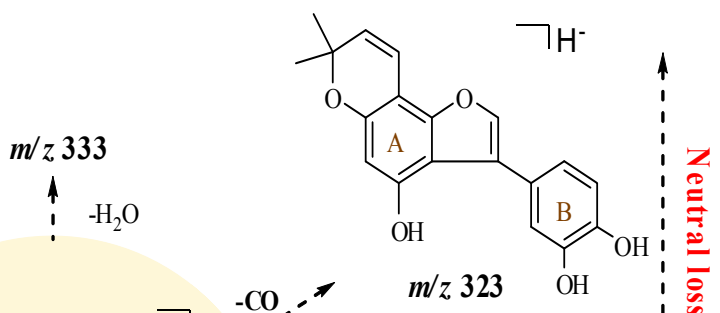

$7 \mathrm{H}^{-}, \mathrm{CO},-$,
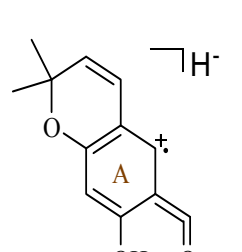

m/z 201

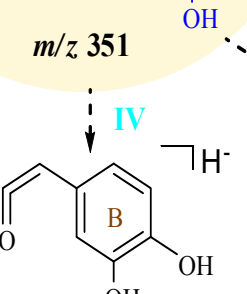

$m / z 149$

B 


\subsection{Extraction and Isolation}

The dried and pulverized stem of $F$. tikoua Bur. $(2.0 \mathrm{~kg})$ was extracted three times ( $4 \mathrm{~h}$ each time) under reflux with analytical grade methanol. The whole extract was filtered and evaporated under reduced pressure at $40-45{ }^{\circ} \mathrm{C}$ using a rotary evaporator. The residue $(127.0 \mathrm{~g})$, equivalent to $6.35 \%$ of the weight of the dried sample, was suspended in water $(2 \mathrm{~L})$ and partitioned three times with ethyl acetate. The ethyl acetate fraction (31 g) was subjected to a silica gel column (500 g, 200 300 mesh, Qingdao Marine Chemical Co. Ltd., Shandong, China) and eluted with the mixture of petroleum ether-acetone-methanol of increasing polarity as eluent. Seventy fractions of $c a .500 \mathrm{~mL}$ each were collected. After analysis with thin-layer chromatography, similar fractions were combined to afford ten fractions. Then, the antifungal activities against $P$. infestans of those fractions were evaluated. The most active fraction, Fr-III (2.37 g), was injected to Sephadex LH-20 column $(3.0 \times 100 \mathrm{~cm}, 100 \mathrm{~g})$, and eluted successively with methanol. Then, the active fractions were further purified by ODS-AP flash chromatography (50 $\mu \mathrm{m}$, Daiso Co. Ltd., Osaka, Japan) and semi-preparative Shimadzu 6 AD HPLC apparatus (Shimadzu Co. Ltd., Tokyo, Japan) with a $\mathrm{C}_{18}$ preparative column $(20 \times 250 \mathrm{~mm}$, $10 \mu \mathrm{m}$, flow rate $8.0 \mathrm{~mL} / \mathrm{min})$. In this way, compounds $\mathbf{1}-\mathbf{3}$ were obtained.

\subsection{Microorganism and Preparation of Zoosporangia Suspension}

The tested fungal pathogen, $P$. infestans was provided by the Institute of Plant Disease, Northwest A\&F University. The strain was retrieved from the storage tube and cultured for 10 days at $16{ }^{\circ} \mathrm{C}$ on rye A agar (rye infusion from $60 \mathrm{~g} \cdot \mathrm{L}^{-1}, 20 \mathrm{~g} \cdot \mathrm{L}^{-1}$ sucrose, and $15 \mathrm{~g} \cdot \mathrm{L}^{-1}$ agar) plates. The plates were then flooded with sterile distilled water, and the zoosporangia were scraped with a glass stick. Mycelial debris was removed by filtration through double-layer cheesecloth, and the zoosporangia were harvested and suspended in sterile distilled water containing $0.1 \%(v / v)$ Tween 20 . The zoosporangia were counted using a hemocytometer and adjusted to $1.0 \times 10^{6}$ zoosporangia $\mathrm{L}^{-1}[19,20]$.

\subsection{Spore Germination (Zoospore Release from Zoosporangia) Assay}

Compounds 1-3 (10 mg) were dissolved in dimethyl sulfoxide (DMSO, $0.1 \mathrm{~mL}$ ) and diluted with sterile distilled water (containing $0.1 \%$ Tween 20 ) to prepare $10 \mathrm{~mL}$ stock solution, which were further diluted to prepare test solutions in which the final concentration of DMSO was $<1 \%(v / v)$. A series of concentrations and one control (1\% DMSO in sterile distilled water) were separately tested for zoospore release from zoosporangia of $P$. infestans. The samples were inoculated with zoosporangia suspension of $P$. infestans containing $1.0 \times 10^{6}$ zoosporangia $\cdot \mathrm{L}^{-1}$. Aliquots of $10 \mu \mathrm{L}$ of prepared zoosporangia suspension were placed on separate glass slides in triplicate. Approximately 300 zoosporangia were observed with a light microscope after the slides containing the zoosporangia were incubated in a moist chamber at $16{ }^{\circ} \mathrm{C}$ for $6 \mathrm{~h}$, and the percentages of zoospore release were calculated. Pyrimethanil (a commercial fungicide) was chosen as a positive control. Pyrimethanil inhibits the secretion of a disease protein. This fungicide exhibits potent antifungal activity against Pseudoperonospora cubensis, Plasmopara viticola, Botrytis cinerea, Phytophthora infestans, and so on [21]. The bioassay data of the antifungal activities were analyzed using SPSS 13.0 for Windows. 


\subsection{Chemistry}

5,3',4'-trihydroxy-2",2"-dimethylpyrano(5",6":7,8) isoflavone (1): $\mathrm{C}_{20} \mathrm{H}_{16} \mathrm{O}_{6}, \mathrm{mp} 210-213{ }^{\circ} \mathrm{C}$; UV $\lambda_{\max }(\mathrm{MeOH}): 289 \mathrm{~nm} ;[\alpha]_{\mathrm{D}}+19.0^{\circ}(\mathrm{MeOH}, c 1.0)$, IR $\left(\mathrm{KBr}, \mathrm{cm}^{-1}\right): 3410,1686,1580 ;{ }^{1} \mathrm{H}-\mathrm{NMR}$ $(\mathrm{MeOD}, 500 \mathrm{MHz}) \delta 8.01(1 \mathrm{H}, \mathrm{s}, \mathrm{H}-2), 7.03\left(1 \mathrm{H}, \mathrm{d}, J=8.3 \mathrm{~Hz}, \mathrm{H}-5^{\prime}\right), 6.68(1 \mathrm{H}, \mathrm{d}, J=10.1 \mathrm{~Hz}, \mathrm{H}-4 ")$, $6.39\left(1 \mathrm{H}, \mathrm{d}, J=2.4 \mathrm{~Hz}, \mathrm{H}-2^{\prime}\right), 6.36(1 \mathrm{H}, \mathrm{s}, \mathrm{H}-6), 6.37\left(1 \mathrm{H}, \mathrm{dd}, J=2.4,8.3 \mathrm{~Hz}, \mathrm{H}-6{ }^{\prime}\right), 5.71(1 \mathrm{H}, \mathrm{d}$, $J=10.1 \mathrm{~Hz}, \mathrm{H}-3 "), 1.45$ (6H, s, H-5", H-6"); ${ }^{13} \mathrm{C}-\mathrm{HMR}(\mathrm{MeOD}, 125 \mathrm{MHz}) \delta 156.85$ (CH-2), 122.66 (C-3), 182.84 (CO-4), 157.58 (C-5), 95.86 (CH-6), 160.90 (C-7), 106.56 (C-8), 158.87 (C-9), 106.93 (C-10), 110.63 (C-1'), 133.23 (CH-2'), 160.25 (C-3'), 157.78 (C-4'), 104.23 (CH-5'), 108.13 (CH-6'), 79.25 (C-2"), 129.67 (CH-3"), 116.09 (CH-4") and 28.55 (2× $\left.\mathrm{CH}_{3}-5 ", 6 "\right)$. ESI-MS/MS: $m / z$ (\%) 351 (30) $[\mathrm{M}-\mathrm{H}]^{-}, 333$ (20) $\left[\mathrm{M}-\mathrm{H}-\mathrm{H}_{2} \mathrm{O}\right]^{-}, 323$ (35) $[\mathrm{M}-\mathrm{H}-\mathrm{CO}]^{-}, 307$ (100) $\left[\mathrm{M}-\mathrm{H}-\mathrm{CO}_{2}\right]^{-}, 265$ (40) $\left[\mathrm{M}-\mathrm{H}-\mathrm{C}_{4} \mathrm{H}_{6} \mathrm{O}_{2}\right]^{-}, 217$ (100) [M-H- $\left.\mathrm{C}_{8} \mathrm{H}_{6} \mathrm{O}_{2}\right]^{-}, 201$ (30) [M-H- $\left.\mathrm{C}_{8} \mathrm{H}_{6} \mathrm{O}_{3}\right]^{-}$. High-resolution ESI-MS: $m / z$ $[\mathrm{M}+\mathrm{H}]^{+}$calcd for $\mathrm{C}_{20} \mathrm{H}_{17} \mathrm{O}_{6} 353.1020$; found 353.1010.

\section{Conclusions}

In summary, a new isoflavone derivative, 5,3',4'-trihydroxy-2",2"-dimethylpyrano (5",6":7,8) isoflavone (1), was isolated using bioactivity-guided bioassay-guided fractionation. The in vitro antifungal activity of $\mathbf{1}$ against $P$. infestans was preliminarily evaluated using the spore germination assay. The $\mathrm{IC}_{50}$ value of $\mathbf{1}$ was $262.442 \mu \mathrm{g} \cdot \mathrm{mL}^{-1}$, which showed the equivalent antifungal activity as a reference fungicide, pyrimethanil with an $\mathrm{IC}_{50}$ value $210.050 \mu \mathrm{g} \cdot \mathrm{mL}^{-1}$.

\section{Acknowledgments}

This study was supported partly by the grant of The National Key Basic Research Program (973 Program, 2010CB126100) from Science and Technology Ministry of China, the National Natural Science Foundation of China (No. 30871663, 30971935), the Program for New Century Excellent Talents in University from Education Ministry of China and the China Postdoctoral Science Foundation (Project No. 20100471644, 201104683).

\section{References}

1. Guan, Y.X.; Yang, X.S.; Tong, L.H.; Yang, B.; Hao, X.J. Chemical constituents in Ficus tikoua of Miao nationality. Chin. Tradit. Herb. Drugs 2007, 38, 342-344.

2. Ahmed, F.; Urooj, A. Traditional uses, medicinal properties, and phytopharmacology of Ficus racemosa: A review. Pharm. Biol. 2010, 48, 672-681.

3. Wei, S.P.; Luan, J.Y.; Lu, L.N.; Wu, W.J.; Ji, Z.Q. A new benzofuran glucoside from Ficus tikoua Bur. Int. J. Mol. Sci. 2011, 12, 4946-4952.

4. Xiang, H.; Wang, X.Y. Studies on antibacterial actions of Ficus tikoua Bur. J. Liupanshui Teachers College 2005, 17, 1-4.

5. Yin, H.Y.; Zhao, Y.C.; Zhang, Y.; Zhang, H.W.; Xu, L.Z.; Zou, Z.M.; Yang, W.P.; Cheng, J.; Zhou, Y.X. Genome-wide analysis of the expression profile of Saccharomyces cerevisiae in response to treatment with the plant isoflavone, wighteone, as a potential antifungal agent. Biotechnol. Lett. 2006, 28, 99-105. 
6. Mabry, T.J.; Markham, K.R.; Thomas, M.B. The Systematic Identification of Flavonoids; Springer Verlag: New York, NY, USA, 1970.

7. Agrawal, P.K. Carbon $^{-13}$ NMR of flavonoids; Elsevier: New York, NY, USA, 1989.

8. Saxena, V.K.; Sharma, D.N. A new isoflavone from the roots of Abrus precatorius. Fitoterapia 1999, 70, 328-329.

9. Schwarz, J.S.P.; Cohen, A.I.; Ollis, W.D.; Kaczka, E.A.; Jackman, L.M. The extractives of piscidia erythrina L.-I: The constitution of ichthynone. Tetrahedron 1964, 20, 1317-1330.

10. Jackson, B.; Owen, P.J.; Scheinmann, F. Extractives from poisonous British plants. Part I. The structure of alpinumisoflavone, a new pyranoisoflavone from Laburnum alpinum J. Presl. J. Chem. Soc. C 1971, 20, 3389-3391.

11. Chibber, S.S.; Sharma, R.P. Derrone, a new pyranoisoflavone from derris robusta seeds. Phytochemistry 1980, 19, 1857-1858.

12. Hughes, R.J.; Croley, T.R.; Metcalfe, C.D. A tandem mass spectrometric study of selected characteristic flavonoids. Int. J. Mass Spectrom. 2001, 210/211, 371-385.

13. Nikolic, D.; Li, Y.; Chadwick, L.R.; Grubjesic, S.; Schwab, P.; Metz, P.; Breemen, R.B. Metabolism of 8-prenylnaringenin, a potent phytoestrogen from hops (Humulus lupulus), by human liver microsomes. Drug Metab. Dispos. 2004, 32, 272-279.

14. Fang, T.Z.; Wang, Y.G.; Ma, Y.; Su, W.W. A rapid LC/MS/MS quantitation assay for naringin and its two metabolites in rats plasma. J. Pharm. Biomed. 2006, 40, 454-459.

15. Lane, G.A.; Newman, R.H. Isoflavones from Lupinus angustifolius root. Phytochemistry 1987, 26, 295-300.

16. Kinoshita, T.; Ichinose, K.; Takahashi, C.; Ho, F.C.; Wu, J.B.; Sankawa, U. Chemical studies on sophora tomentosa: The isolation of a new class of isoflavonoid. Chem. Pharm. Bull. 1990, 38, 2756-2759.

17. Al-Maharik, N.; Botting, N.P. An expedient regioselective synthesis of Lupiwighteone and 8-Prenylapigenin. Tetrahedron 2003, 59, 4177-4181.

18. Kim, J.H.; Chan, K.L.; Mahoney, N.; Campbell, B.C. Antifungal activity of redox-active benzaldehydes that target cellular antioxidation. Ann. Clin. Microbiol. Antimicrob. 2011, 10, doi:10.1186/1476-0711-10-23.

19. Gyamfi, M.A.; Yonamine, M.; Aniya, Y. Free-radical scavenging action of medicinal herbs from Ghana: Thonningia sanguinea on experimentally-induced liver injuries. Gen. Pharmacol. 1999, 32, 661-667.

20. Bozin, B.; Mimica, D.M.; Simin, N.; Anackov, G. Characterization of the volatile composition of essential oils of some lamiaceae spices and the antimicrobial and antioxidant activities of the entire oils. J. Agric. Food Chem. 2006, 54, 1822-1828.

21. Sholberg, P.L.; Bedford, K.; Stokes, S. Sensitivity of Penicillium spp. and Botrytis cinerea to pyrimethanil and its control of blue and gray mold of stored apples. Crop. Prot. 2005, 24, 127-134.

(C) 2012 by the authors; licensee MDPI, Basel, Switzerland. This article is an open access article distributed under the terms and conditions of the Creative Commons Attribution license (http://creativecommons.org/licenses/by/3.0/). 